\title{
Mitigation of water repellency in the treatment of contaminated muds using the chemical-biological stabilization process
}

\author{
F. J. Guzmán-Osorio $\cdot$ R. H. Adams
}

Received: 1 October 2013/Revised: 3 March 2014/ Accepted: 28 April 2014/Published online: 20 May 2014

(C) Islamic Azad University (IAU) 2014

\begin{abstract}
The soil-water relationship was used to evaluate the efficacy of a novel remediation technology, the chemical-biological stabilization process, which focuses principally on soil fertility restoration in agricultural sites. This process was evaluated for the treatment of $150 \mathrm{~m}^{3}$ of bentonitic drilling muds from a closed sulfur mine which contained $70 \%$ fines $(<0.05 \mathrm{~mm})$, and which had been contaminated with very weathered hydrocarbons, containing $31 \%$ asphaltenes. This material was monitored for two and a half years, for in situ moisture content, field capacity, and soil water repellency. Additionally, critical soil moisture content for water drop penetration times of $<5$ and $<60 \mathrm{~s}$ was monitored. Field capacity increased $46.6 \%$ with respect to initial values and a vigorous vegetative growth was established. Concurrently, water repellency values for molarity ethanol droplet and water drop penetration times were reduced from 5.1 to $3.9 \mathrm{M}$ and 106 to $0.12 \mathrm{~h}$, respectively. Soil in situ moisture content during the driest part of the year $(20.3 \%$ humidity) remained above critical values (15.1\% humidity and $19.5 \%$ humidity) to avoid a water repellency of $<5$ and $<60 \mathrm{~s}$, respectively, and water repellency was not observed in the field. Thus, complete mitigation of water repellency was achieved. These
\end{abstract}

F. J. Guzmán-Osorio · R. H. Adams ( $₫)$

División Académica de Ciencias Biológicas, Universidad Juárez Autónoma de Tabasco, Carretera Villahermosa - Cárdenas km 0.5 , entronque a Bosques de Saloya, $\mathrm{s} / \mathrm{n}$, Villahermosa, Tabasco, Mexico

e-mail: drrandocan@hotmail.com findings indicate that the soil-water relationship should be evaluated to achieve an integral soil remediation and that water repellency as a remediation criterion should be complemented with determinations of critical moisture content and actual site information on soil in situ moisture content during the annual cycle.

Keywords Critical moisture content .

Fertility restoration - Field capacity · Hydrophobicity

\section{Introduction}

The majority of soil remediation programs focus mainly on the reduction in hydrocarbon concentration. This is based on the supposition that the principal impacts are toxicity and potential to produce contaminated leachates and that these are directly related to hydrocarbon concentration (Torres et al. 2007; Abdulsalam et al. 2011; Khamforoush et al. 2013). Nonetheless, interference in soil-water interactions are frequently more damaging, especially for sites contaminated with very weathered, viscous hydrocarbons (Li et al. 1997). Therefore, the type of hydrocarbons in the soil and their interaction with soil surfaces can be more important than the overall hydrocarbon concentration in terms of soil restoration. As a consequence of the interruption of these interactions, the soil may present problems with the availability of water necessary for the growth of vegetation and microbial activity (Li et al. 1997; Roy and McGill 1998; Adams et al. 2008). Roy and McGill (1998) discovered several sites with old spills in oil fields in Alberta, Canada, with very low concentrations of hydrocarbons, but nonetheless, complete loss of soil structure and little or no vegetative cover, even after decades of natural attenuation. Similarly, Adams et al. (2008) 
encountered soil in southern Mexico, which had been bioremediated to low hydrocarbon levels and in accordance with Mexican legal norm, but which still presented severe effects of water repellency, low field capacity, and greatly diminished plant productivity. Recently, Nieber et al. (2011) have also reported on the problem of water repellency and severely eroded soil at an old spill site in northern Minnesota, USA. In all of these sites, severe soil deterioration has resulted from the water repellency caused by the residual hydrocarbons in the soil-even in low concentrations.

Common methods for measuring water repellency include the Water Drop Penetration Time (WDPT) and the Molarity Ethanol Drop (MED) methods (Jaramillo 2006; Ritsema et al. 2008; King 1981; Watson and Letey 1970; Letey et al. 2000; Roy and McGill 2002). In 2008, Adams et al. modified the MED test to obtain greater precision of the MED value and to estimate the WDPT in strongly water repellent soils. In this study, the MED method was used, but the time that the water drop takes to penetrate the soil was measured even if greater than $10 \mathrm{~s}$. The data were then graphed with the ethanol molarity as the independent variable and the water penetration time as the dependent variable. Typically, the data correspond to an exponential decay function which can be interpolated (to a WDPT of $10 \mathrm{~s}$ ) to determine the MED value with greater precision. This function can also be extrapolated (to an ethanol molarity of zero) to estimate the WDPT, assuming that the water drop would not evaporate.

In addition to these parameters, another has been used to evaluate the potential for water repellency in the field: the critical soil moisture content (Dekker et al. 2001). In this method, the WDPT is measured but instead of using dry soil, the penetration times at different water contents are determined. The standard WDPT test is performed on dry soil, but in the field, there may still be some moisture in the soil, even during the driest months. Since water repellency decreases with increasing moisture content, this may reduce the risk of developing water repellency in an actual field setting. In this test, the soil moisture necessary to reduce the water penetration time to low values (say less than $5 \mathrm{~s}$, or less than $60 \mathrm{~s}$ ) is determined. Soils with higher critical moisture contents may develop water repellency even when the soil is not very dry. Thus, this parameter can be used to evaluate the potential to present water repellency in the field. The combination of these parameters may be considered to be very important for the evaluation of the remediation of soil contaminated with hydrocarbons as well as for treatment of contaminated drilling cuttings.
In the present study, the water repellency and the mitigation thereof were studied in a field scale remediation pilot test. Previously, the technology used for the remediation (the chemical-biological stabilization method) had been evaluated at laboratory scale ( $\sim 20 \mathrm{~kg}$, Adams and Guzmán-Osorio 2008) using the same contaminated muds. The material used for both the laboratory scale study and field scale study came from a contaminated sediment beach in a waste holding dam. It consisted of bentonitic drilling muds with some sandy backfill. This material had been contaminated with very weathered hydrocarbons at concentrations of 5-7 \% (Adams and Guzmán-Osorio 2008; Guzmán et al. 2004). In the laboratory scale study, controls were incorporated in which the contaminated material was excavated and simply placed in a cell without treatment. While the treatment cells showed a reduction in toxicity and vigorous plant growth, the control cells showed no change in hydrocarbon concentration, no reduction in toxicity, and no vegetative cover for several years, with only poor growth of grasses and weeds later. Thus, this laboratory scale study demonstrated the advantage of this remediation technology as compared to natural attenuation and established proof of process.

Subsequently, this technology was evaluated at field scale (Adams et al. 2013). In this study, a reduction in hydrocarbon concentration of nearly one-half and the complete reduction in toxicity were observed. Furthermore, there was a reduction in hydrocarbons in soil leachates to low levels $(\sim 1 \mathrm{mg} / \mathrm{L})$, complete vegetative cover, and good soil respiration rates, comparable to uncontaminated soils in similar tropical areas. Important information with respect to the scale-up of this technology was generated in this study, especially with respect to moisture management and $\mathrm{pH}$ control for an effective remediation.

One factor which was discovered during the field scale study was the potential problem for normal soilwater interactions in the contaminated soil. Many authors have cited the problem of water repellency and reduced field capacity that can be encountered in hydrocarbon contaminated soils (Roy and McGill 1998; Litvina et al. 2003; Adams et al. 2008; Nieber et al. 2011). In the current study, we report on these aspects of water repellency and field capacity that were investigated during the field scale evaluation of this technology, but which we could not include in the previous paper due to size limitations. This research was carried out and monitored for $2 \frac{1}{2}$ years, between October 2007 and March 2010 in Cosoleacaque, Veracruz, Mexico. 


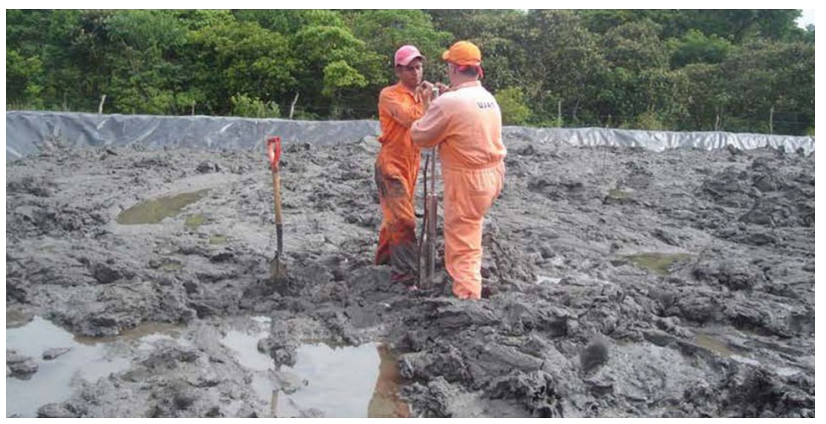

Fig. 1 Contaminated material from the Agua de Mina dam before treatment. The muddy aspect of this material without structure is evident

\section{Materials and methods}

\section{Experimental design}

The contaminated material $\left(150 \mathrm{~m}^{3}\right)$ was collected from the Agua de Mina dam, in the Texistepec Mining Unit (Unidad Minera Texistepec, in Spanish), located in the southern part of Veracruz state, Mexico (geographic coordinates: $17^{\circ} 52.441^{\prime} \mathrm{N}, 94^{\circ} 44.985^{\prime} \mathrm{W}$ ). This material was a mixture of bentonitic muds (generated during the drilling of sulfur extraction wells), hydrocarbons and sulfur (both originating from the salt domes from which the sulfur was extracted), and some backfill. It had a silty-loam texture $(71 \%$ fines, $<0.05 \mathrm{~mm})$, a hydrocarbon concentration of approximately $48,000 \mathrm{mg} \mathrm{kg}^{-1}$, a $\mathrm{pH}$ of 6.8, and an electrical conductivity of $0.004 \mathrm{dS} \mathrm{m}^{-1}$. The hydrocarbons in the material were extremely weathered $\left(1.05 \mathrm{~g} / \mathrm{cm}^{3}, 31 \%\right.$ asphaltenes $)$. A treatment cell with dimensions of $15 \mathrm{~m} \times 20 \mathrm{~m}$ was built with a typical land-farm design, including earthen berms $\sim 1.2 \mathrm{~m}$ high, a $1 \%$ grade, 30 mil high-density polyethylene liner (thermally sealed), a sandy leachate collection layer $(\sim 10 \mathrm{~cm}$ deep), and flow to a leachate recollection pit (see Adams et al. 2013). Contaminated material from the mining unit was placed in the cell to a depth of $\sim 60 \mathrm{~cm}$ and treated by the chemical-biological stabilization process (Adams 2004, see Fig. 1). This cell was subsequently monitored for 865 days. During each sampling, 12 split-spoon cores were collected distributed evenly across the cell from the surface to the sandy leachate layer. To reduce variability, these were mixed together, homogenized, and divided into four lots (composite samples) for analysis. Water repellency was analyzed using the MED and WDPT methods (Adams et al. 2008). Soil moisture content, field capacity (FC), and critical moisture content (percent humidity to reduce WDPT to less than 5 and $60 \mathrm{~s}$ ) were also measured. The climate in this area is tropical monsoon (Am in the Köppen classification system) tending toward tropical wet-and-dry (Aw) (Peel et al. 2007), with an average temperature of $\sim 27{ }^{\circ} \mathrm{C}$ and an annual precipitation of about $1,800 \mathrm{~mm}$.

\section{Chemical-biological stabilization}

The contaminated material was treated by adding $4 \%$ $\mathrm{Ca}(\mathrm{OH})_{2}$ (dry weight basis), followed by the addition of $4 \%$ sugar cane cachasse (dry weight basis), a fine-fibered agricultural waste (sugar mill filtrate cake). These were mixed in thoroughly using a backhoe at each stage of treatment. After the soil had dried sufficiently and the $\mathrm{pH}$ dropped to about eight, a fine-rooted tropical $\mathrm{C}-4$ grass (Brachiaria humidicola) was planted by seed (Adams 2004).

\section{Monitoring}

During a period of nearly $2 \frac{1}{2}$ years, different parameters were monitored in the treated material. It was considered adequate to monitor for this time period, as more than two complete annual cycles were observed and an excellent vegetative cover was established, with complete reduction in toxicity and recovery of microbial activity to levels similar to other healthy soils in tropical conditions (Adams et al. 2013). It is likely that the high temperatures and humidity in this tropical monsoon climate were important factors in this relatively rapid soil restoration (Adams et al. 2013).

Twelve samples evenly distributed in the treatment cell were collect using a split-spoon corer, sampling from the soil surface to the sand leachate collection layer. These were mixed together, homogenized, and divided into four composite samples. Among the parameters analyzed were percent humidity $(\% \mathrm{H}$, also known as soil moisture content), field capacity (FC), and water repellency using the MED and WDPT methods (Adams et al. 2008).

Determination of water repellency using the molarity ethanol drop (MED) and water drop penetration time (WDPT) methods

The molarity ethanol drop (MED) value for water repellency severity was measured in samples which were air-dried, hand ground, and screened $(<2 \mathrm{~mm})$. Solutions of denatured ethanol were prepared in deionized water in a range of concentrations from 1 to $6 \mathrm{M}$, in $0.25 \mathrm{M}$ intervals. Dry soil was spread out 
evenly in a glass petri dish, and the time necessary for a drop of ethanol solution to penetrate the soil was measured (Roy and McGill 2002). The results for each sample were used to determine the exponential type correlation between penetration time and ethanol molarity (Adams et al. 2008). The interpolation of this function was used to determine the ethanol molarity corresponding to a penetration time of $10 \mathrm{~s}$. The sample function was also used to calculate the WDPT, extrapolating for an ethanol molarity of zero. The correlation coefficients of these functions were $r>0.99$ in the majority of cases $\left(r_{\text {average }}=0.99\right)$. The WDPT was determined in this way because the soil was so repellent that direct measurement was not feasible (WDPT $>1 \mathrm{~h}$ ). However, in the last sampling period, WDPT values were observed directly (with de-ionized water) and compared to the calculated values from the penetration time versus ethanol molarity function. Both the MED values and WDPT values were evaluated prior to and after treatment using the Kruskal-Wallis statistical test with a $95 \%$ confidence interval, as per McDonald (2009).

\section{Critical humidity (critical soil moisture content)}

Critical humidity, also known as the critical soil moisture content, is the percent humidity (moisture content) above which the soil does not present water repellency (Dekker and Ritsema 1994; Lichner et al. 2006). Direct measurement of penetration times of de-ionized water were made to determine the critical humidity for absorption at $<5$ and $<60 \mathrm{~s}$ (non-repellent to slightly repellent range, according to Dekker and Jungerius 1990). The soil sample was moistened using a fine spray of water and mixing to achieve penetration until it was observed that a water drop could be absorbed rapidly $(<1 \mathrm{~s})$. The measurement was made starting with a moist sample and subsequently drying the soil in an oven $\left(35-40{ }^{\circ} \mathrm{C}\right)$, after which the measurement was repeated on ever increasingly drier soil. In this way, WDPT was obtained at different moisture percentages for each sample. The data were graphed to obtain the penetration time versus $\% \mathrm{H}$ function, and the $\% \mathrm{H}$ corresponding to penetration times of $5 \mathrm{~s}$ and $60 \mathrm{~s}$ was calculated by interpolation.

Field capacity

Field capacity was measured as the percent humidity (soil moisture content) of a sample after being saturated

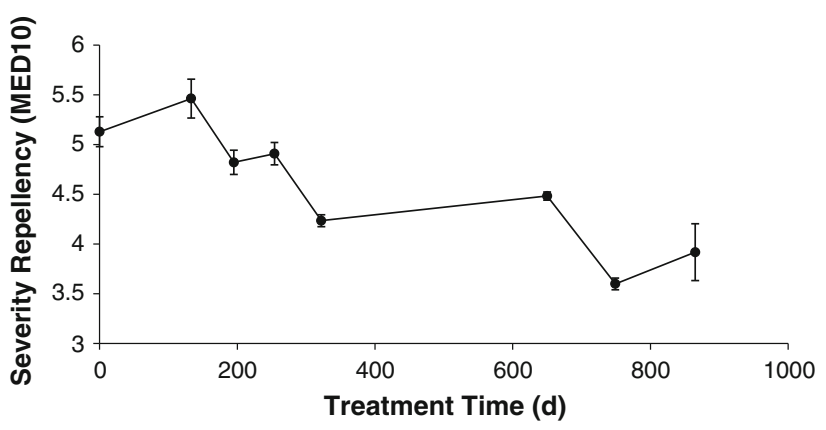

Fig. 2 Water repellency severity (MED values) during the treatment period. Data points indicate the average of four samples, and bars indicate the SD

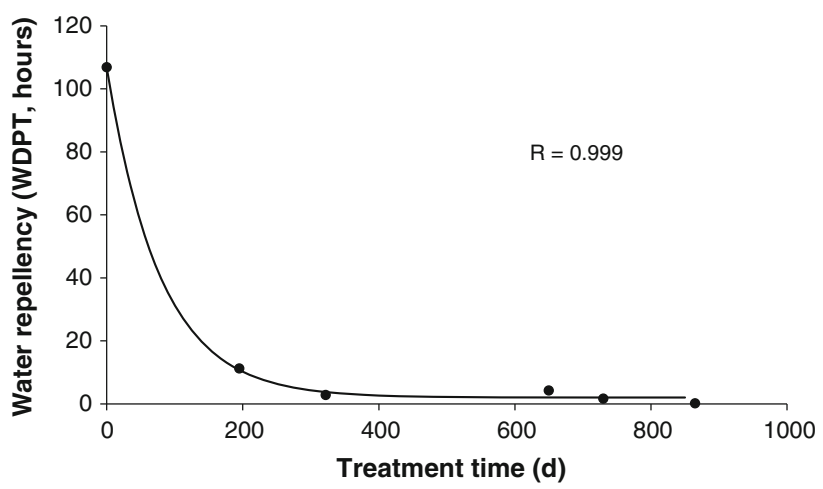

Fig. 3 Relationship between WDPT values (calculated by extrapolation) and treatment time. Data points indicate the average of four samples

with water and allowing free drainage of the soil using the Coleman tube method (Aguilar-Santelises 1988, as cited in Rascón Alvarado et al. 2008). In this test, approx. $100 \mathrm{~g}$ of soil was placed in a receptacle with upright walls and with perforations in the base. Subsequently, water was added to saturate the sample. The water in the sample was let to drain for $24 \mathrm{~h}$, and the moist sample was weighed (Zavala-Cruz et al. 2005). Then, the sample was dried in an oven to constant weight, and the percent humidity was calculated with respect to the moist sample. The FC values were evaluated using the Kruskal-Wallis statistical test with a $95 \%$ confidence interval (McDonald 2009).

\section{Results and discussion}

During the $2 \frac{1}{2}$ years of treatment, the MED values decreased $24 \%$ (from 5.13 to $3.9 \mathrm{M}$, Fig. 2). An 

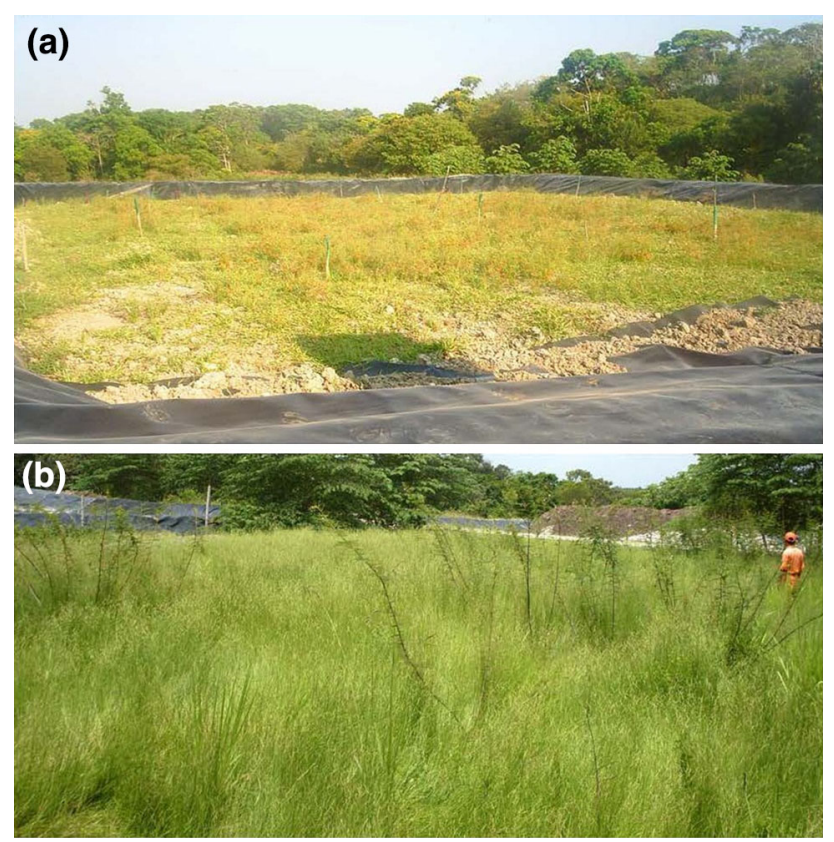

Fig. 4 Pasture growth in the treatment cell. a At 254 days and during the driest part of the year (May). b After 700 days, during the second rainy season (mid August)

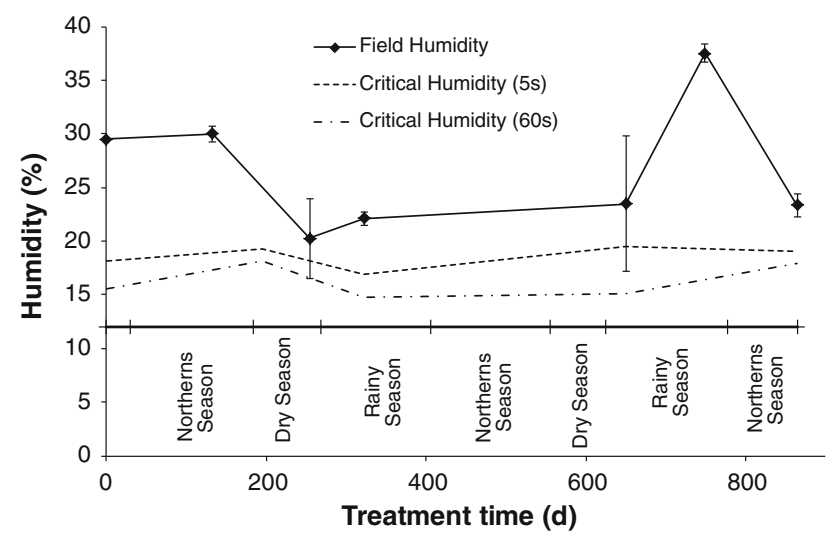

Fig. 5 Average values for soil moisture content (humidity) in the field compared to critical values for $<5$ and $<60 \mathrm{~s}$. In the lower part of the figure, the scale of seasons in this region is shown. Data points indicate the average of four samples, and bars indicate the SD

increase or $5.6 \%$ was observed at $133 \mathrm{~d}$ which may have been related to the addition of organic material (cachasse) at the begging of the treatment (Moral-Garcia et al. 2003). Oscillations in the MED value were also observed, possibly due to de interactions between the hydrocarbons, the organic material, and the soil surfaces (Litvina et al. 2003). Although there was a statistically significant difference between the starting and final values $(P<0.05)$, the MED value at the end of

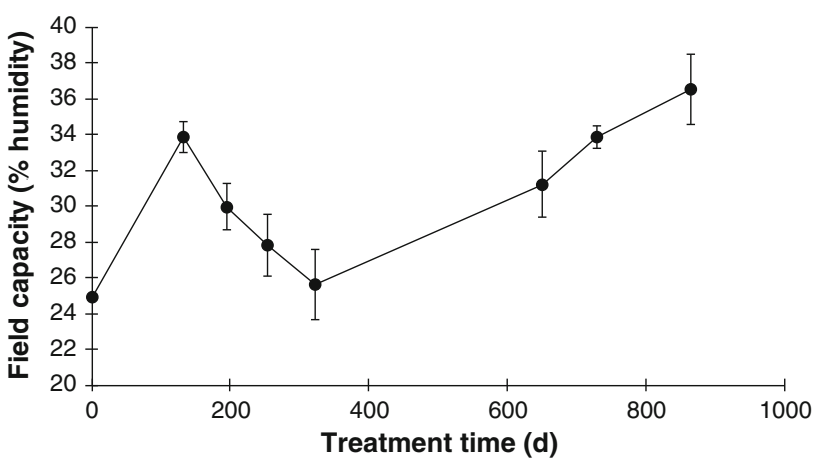

Fig. 6 Field capacity (percent humidity) during treatment. Data points indicate the average of four samples, and bars indicate the SD

monitoring still was high, corresponding to a severe level (MED > 3.2), according to the scale proposed by King (1981).

Due to the high persistence of repellency, it was not possible to obtain WDPT values directly; therefore, these were calculated by extrapolation from the MED results (see Materials and Methods section). The values of WDPT were reduced more than $99 \%$ (from 106 to $0.12 \mathrm{~h}$ ) and were statistically significant $(P<0.05)$. A large part of this reduction was produced during the first $200 \mathrm{~d}$ after applying the treatment, Fig. 3. Nonetheless, the final value of WDPT was $7.2 \mathrm{~min}$, which is still considered strongly repellent according to the scale proposed by Dekker and Jungerius (1990). It should be pointed out that these determinations were made on air-dried soil, and therefore may be very different from that in the field, where the soil was observed to maintain a relatively high moisture content through out the year (approximately $20-37 \%$ humidity).

Although the water repellency severity (MED) and persistence (WDPT) values indicate that the treated material still had strong to severe hydrophobicity, in the field the grass planted did not appear to suffer from water availability and showed an exuberant growth and normal root development (Fig. 4a), even during the driest part of the year.

Upon observing these conditions in the field, the question arises as to why the vegetation does not appear water stressed with these levels of hydrophobicity (i.e., the MED and WDPT values). To try to obtain a possible explanation to these observations, critical humidity tests were run. Critical humidity varied from 16.9 to $19.5 \%$ for water penetration times of $<5 \mathrm{~s}$, and from 15.1 to $15.5 \%$ for penetration times of $<60 \mathrm{~s}$, both in treated and untreated 
material. During the driest part of the year, during May before the first rains, the soil moisture content in the field was $20.3 \%$ (possibly the lowest during the year), which is above the critical moisture content value (Fig. 5), such that hydrophobic condition in the field in the treated material was not experienced.

One possible reason that the soil moisture content in the field remained high (and above critical levels) could be that the FC was high enough to maintain this moisture level, capturing more moisture during precipitation events. Field capacity, during the start of treatment, was $24.9 \% \mathrm{H}$ which increased to $33.8 \% \mathrm{H}$ during the first $4 \frac{1}{2}$ months, probably due to the addition of the organic amendment (Jabro et al. 2009). After $61 / 2$ months, the FC dropped to $25 \% \mathrm{H}$, possibly due to the partial decomposition of the organic material added at the start. Nonetheless, during the next year and a half (17.8 months) the FC increased to $36.5 \% \mathrm{H}$ probably to the increase in humic substances produced by the microbial activity in the rhizosphere (Piccolo et al. 1996; Liem et al. 2003; Suganya and Sivayami 2006). During this same period, a vigorous vegetative growth was established. The overall increase in FC was $46.6 \%$ with respect to the initial value. Furthermore, this appears to be sustainable, rising in the second year of treatment, and after the initial decrease in FC (see Fig. 6).

This increase in FC was statistically significant $(P<0.05)$ and can have important implications for maintaining soil moisture during the driest period of the year, such that it is not reduced to below the critical moisture content for water repellency. This would permit the complete vegetative cover, vigorous growth, and transformation of this geological substrate (bentonitic drilling muds) into a soil-like material apt for agriculture or pasture.

This is the first study to the authors' knowledge of the demonstration of complete soil restoration in a remediation process. In addition to the elimination of toxicity and hydrocarbon concentrations in soil leachates, as well as the restoration of soil microbial activity, root density, and pH (demonstrated previously in Adams et al. 2013), this method also restores the normal soil-water relationship, increasing FC, and reducing water repellency to levels which permit a vigorous plant growth (present study). Additionally, this study is the first of its kind that identifies and measures the soil water repellency in a remediation project in the context of in situ soil moisture content with respect to critical soil moisture content-a useful metric to evaluate the success in overcoming soil water repellency caused by petroleum contamination in soil.

\section{Conclusion}

The focus on the soil-water relationship and the use of fertility parameters in general are important for establishing clean up criteria for the remediation of hydrocarbon contaminated sites in agricultural areas. As seen in this study, relatively high values or MED and WDPT do no necessarily indicate problems with soil moisture, and these need to be complemented with critical moisture values and actual site data with respect to in situ soil moisture content during the annual cycle. Furthermore, the increase in FC provided by the addition of organic conditioners may effectively mitigate potential problems with critical humidity and therefore, water repellency.

During the first months of this semi-passive treatment, the establishment of a vegetative cover is important. It is very probable that the production of humic substances in the rhizosphere counters the loss of organic material due to decomposition and helps maintain field capacity at a high level.

Acknowledgments This study is part of a research project entitled "Industrial Scale-up of the Chemical-Biological Stabilization Process for Contaminated Soils from the Agua de Mina Sediment Beach in the Texistepec Mining Unit, Municipality of Texistepec, Vercruz,' funded jointly by the Remediation Laboratory of the Academic Division of Biological Sciences (Universidad Juárez Autónoma de Tabasco) and an industrial partner, Comunicaciones y Electrónica Industrial S.A. de C.V. (CEISA); Grant No. UJAT-CEISA 010507/POA20070751. We are grateful to Mr. Oscar Domingo Danglada Alarcón of CEISA for co-sponsoring this research and also to Mr.Héctor López Guerrero and Mr. Juan Avila Gonzales (both from Pemex Gas y Petroquímica Básica) for their assistance with access to the Mining Unit to obtain material for treatment.

\section{References}

Abdulsalam S, Bugaje IM, Adefila SS, Ibrahim S (2011) Comparison of biostimulation and bioaugmentation for remediation of soil contaminated with spent motor oil. Int J Environ Sci Technol 8(1):187-194. http://www.bioline.org.br/pdf?st11018

Adams RH (2004) Chemical-biological stabilisation of hydrocarbon contaminated soil and drilling cuttings in tropical Mexico. Land Cont Reclam 12(4):349-361. http://dl.dropboxusercontent.com/ u/67964190/12-04-05.pdf

Adams RH, Guzmán-Osorio FJ (2008) Evaluation of land farming and chemico-biological stabilization for treatment of heavily contaminated sediments in a tropical environment. Int $\mathrm{J}$ Environ Sci Technol 5(2):169-178. http://www.bioline.org.br/pdf?st08020 
Adams RH, Guzmán-Osorio FJ, Zavala-Cruz J (2008) Water repellency in oil contaminated sandy and clayey soils. Int $\mathrm{J}$ Environ Sci Technol 5(4):445-454. http://www.bioline.org.br/ pdf?st08049

Adams RH, Guzmán-Osorio FJ, Domínguez-Rodríguez VI (2013) Field scale evaluation of the chemical-biological stabilization process for the remediation of hydrocarbon contaminated soil. Int J Environ Sci Technol. doi:10.1007/s13762-013-0321-1

Aguilar-Santelises A (1988) Métodos de análisis de suelos. Sociedad Mexicana de la Ciencia del Suelo, Chapingo, Estado de México

Dekker LW, Jungerius PD (1990) Water erosion in the dunes. Catena Suppl 18:185-193

Dekker LW, Ritsema CJ (1994) How water moves in a water repellent sandy soil. Part 1: potential and actual water repellency. Water Resour Res 30(9):2507-2517. doi:10.1029/94WR007749 (July 2010)

Dekker LW, Doerr SH, Oostindie K, Ziogas AK, Ritsema CJ (2001) Water repellency and critical soil water content in a dune sand. Soil Sci Soc Am J 65(6):1667-1674. http://library.wur.nl/ WebQuery/wurpubs/314019

Guzmán FJ, Adams RH, Avila J (2004). Comparison of biostimulation, bioaugmentation and chemical-biological stabilization for remediation of hydrocarbon contaminated sediments. In: 11th International environmental petroleum conference international environmental petroleum consortium. Albuquerque, NM, 11-15 Oct 2004. http://ipec.utulsa.edu/Conf2004/Papers/guzman_ adams_avila.pdf

Jabro JD, Evans RG, Kim Y, Iversen WM (2009) Estimating in situ soil-water retention and field water capacity measurements in two contrasting soil textures. Irrig Sci 27:223-229. http://naldc. nal.usda.gov/catalog/50325

Jaramillo JDF (2006) Repelencia al agua en suelos: una síntesis. Rev Ac Colomb Cienc 30(115):215-232. http://www.accefyn.org.co/ revista/Vol_30/115/115_215_232.pdf

Khamforoush M, Bijan-Manesh MJ, Hatami T (2013) Application of the Haug model for process design of petroleum hydrocarboncontaminated soil bioremediation by composting process. Int $\mathrm{J}$ Environ Sci Technol 10(3):533-544. doi:10.1007/s13762-012$0129-4$

King PM (1981) Comparison of methods for measuring severity of water repellence of sandy soils and assessment of some factors that affect its measurement. Aust J Soil Res 19:275-285

Letey J, Carrillo MLK, Pang XP (2000) Approaches to characterize the degree of water repellency. J Hydrol 231-232:61-65. http:// www.envsci.rutgers.edu/ gimenez/SoilPhysics/Homework02/ LeteyEtA2000.pdf

Li X, Feng Y, Sawatsky N (1997) Importance of soilwater relations in assessing the endpoint of bioremediated soils. I. Plant growth. Plant Soil 192(2):219-226. http://download.springer.com/static/ pdf/796/art\%253A10.1023\%252FA\%253A1004280626976.pdf? auth66=1380239774_79b0f436bf27898b71f275994a6c75d8\&ext=. pdf

Lichner L Dlapa P, Doerr SH, Mataix-Solera J (2006) Evaluation of different clay minerals as additives for soil water repellency alleviation. Appl Clay Sci 31:238-248. http://ac.els-cdn.com/ S0169131705001456/1-s2.0-S0169131705001456-main.pdf? tid=44ffef $24-2575-11$ e3-b71c-00000aab0f $27 \&$ acdnat $=1380067 \overline{3}$ 15_12c7d51f6e2c9e48d56cde6bac05a172

Liem LE, Facey RM, Fischer M (2003) Enhanced hydrocarbon bioremediation through the addition of humic substances part II: improved land treatment and static pile composting. In: Remediation technologies symposium 2003, 15-17 Oct. Banff, AL,
Canada. http://www.esaa-events.com/remtech/2003/pdf/Liem Facey.pdf

Litvina M, Todoruk TR, Langford CH (2003) Composition and structure of agents responsible for development of water repellency in soils following oil contamination. Environ Sci Technol 37(13):2883-2888. http://pubs.acs.org/doi/abs/10.1021/ es0262961

McDonald JH (2009) Handbook of biological statistics (2nd ed). Sparky House, Baltimore. http://udel.edu/ mcdonald/statkrus kalwallis.html

Moral-Garcia FJ, Dekker LW, Oostindie K, Ritsema CJ (2003) Soil water in the natural park of Donana, Southern Spain. In: Ritsema CJ, Dekker LW (eds) Soil water repellency; occurrence, consequences, and amelioration, pp 121-127. http://store. elsevier.com/Soil-Water-Repellency/isbn-9780080523217/

Nieber J, Severson L, Green N (2011) Hydrologic characteristics of contaminated soils at the national crude oil spill fate and natural attenuation research site. 2011. In: Geological Society of America annual meeting in Minneapolis (9-12 October). Paper No. 136-1. https:/gsa.confex.com/gsa/2011AM/finalprogram/ abstract_193916.htm

Peel MC, Finlayson BL, McMahon TA (2007) Updated world map of the Köppen-Geiger climate classification. Hydrol Earth Syst Sci 11:1633-1644. http://hal.archives-ouvertes.fr/docs/00/30/50/98/ PDF/hess-11-1633-2007.pdf

Piccolo A, Pietramellara G, Mbagwu JSC (1996) Effects of coal derived humic substances on water retention and structural stability of Mediterranean soils. Soil Use Manag 12(4):209-213. http://onlinelibrary.wiley.com/doi/10.1111/j.1475-2743.1996. tb00545.x/abstract

Rascón Alvarado E, Peña Cervantes E, López Cervantes R, Cantú Sifuentes M, Narro Farías EA (2008) Impacto en algunas propiedades físicas del suelo por aplicación de aguas residuales. Terra Latinoamericana 26(1):69-74. http://www.chapingo.mx/ terra/?module $=$ resumenes $\&$ volumen $=26 \&$ numero $=1$

Ritsema CJ, Dekker LW, Oostindie K, Moore D, Leinauer B (2008) Soil water repellency and critical soil water content. In: Soil science: step by step field analysis, pp 97-112 https://dl. sciencesocieties.org/publications/search?search\%5B0\%5D=Soil +water+repellency+and+critical+soil+water+content\&submit $=$ Search\&searchType $\% 5 \mathrm{~B} 0 \% 5 \mathrm{D}=$ Manual\&num-results=10\&stem $=$ false $\&$ sort $=$ relevance $\&$ open-access $=$ false

Roy JL, McGill WB (1998) Characterization of disaggregated nonwettable surface soils found at old crude oil spill sites. Can J Soil Sci 78(2):331-334. http://pubs.aic.ca/doi/pdf/10.4141/ S97-039

Roy JL, McGill WB (2002) Assessing soil water repellency using the molarity of ethanol droplet test. Soil Sci 167(2):83-97. http:// dialnet.unirioja.es/servlet/ejemplar?codigo $=126885$

Suganya S, Sivayami R (2006) Moisture retention and cation exchange capacity of sandy soil as influenced by soil additives. J Appl Sci Res 2(11):949-951. http://www.aensiweb.com/jasr/ jasr/2006/949-951.pdf

Torres LG, Climent M, Saquelares J, Bandala ER, Urquiza G, Iturbe $R$ (2007) Characterization and treatability of a contaminated soil from an oil exploration zone. Int $\mathbf{J}$ Environ Sci Technol 4(3):311-322. http://www.bioline.org.br/pdf?st07039

Watson CL, Letey J (1970) Indices for characterizing soil water repellency based upon contact angle-surface tension relationships. Soil Sci Soc Am P 34(6):841-844. https://dl. sciencesocieties.org/publications/sssaj/abstracts/34/6/SS0340060 841 
Zavala-Cruz J, Gavi-Reyez F, Adams SRH, Ferrera-Cerrato R, Palma-Lopez DJ, Vaquera-Huerta H, Domínguez-Esquivel JM (2005) Derrames de petróleo en suelos y adaptación de pastos tropicales en el Activo Cinco Presidentes, Tabasco, México.

Terra Latinoamericana 23(3):293-302. http://www.chapingo. $\mathrm{mx} /$ terra/index.php? module $=$ resumenes $\& \mathrm{id}=233293$ 